\title{
Creep and Floodplain Defluxion Study in the East of the Russian Plain
}

Kurbanova S.G.a

Gasanov I. M. ${ }^{b}$

\author{
Denmukhametov R.R. ${ }^{c}$
}

abc Kazan Federal University, Institute of Management, Economics and Finance, Kazan, 420008, Russia

\section{Doi:10.5901/mjss.2015.v6n1s3p237}

\begin{abstract}
The phenomenon of a slow displacement of unconsolidated soil that is widely known by the term "creep" (from English creep crawl) and "defluxion" (from German defluktion - drip, leak) covers almost all slopes of dry land. In order to identify the geomorphological role of this phenomenon stationary studies of creep and floodplain defluxion of small rivers in valleys of the Middle Volga are widely held. The relief of the investigated area (on the example of Raifa region of the Greater Volga-Kama Biosphere Reserve (GVKBR) "UNESCO") was created as a result of a long interaction between processes of internal and external dynamics. The territory of the reserve is very heterogeneous in morphology, genesis and history of a landform development. In the future, taking stationary study areas located on slopes and floodplains of small rivers as an example, it is very important to identify significant relationships and dependencies of the interaction between slopes defluxion and floodplain defluxion with modern geomorphic conditions.
\end{abstract}

Keywords: relief, creep, floodplain defluxion, erosion-accumulative processes, incline, floodplain, slope.

\section{Introduction}

Stationary studies conducted by the staff members of the Department of Geography and Cartography of the Kazan University that have been held for over 30 years (since 1983) and include studies of the intensity of modern erosionaccumulative processes in small river basins in the east of the Russian Plain, have identified a new phenomenon at the bottoms of river valleys - the floodplain defluxion (slow ground movement of floodplains down the stream). The study of floodplain defluxion is held in small river basins east of the Russian Plain. The floodplains of these rivers build up modern (Holocene) alluvial formations. They occupy large areas in the valley bottoms. Alluvium of floodplains and the first terrace above the floodplain have a structure typical to the moderately-humid type, in which the channel and floodplain facies are clearly distinguished and periglacial formations are absent. The width of a floodplain alluvium is defined as the sum of the spring tide's median height and the reaches' median depth.

In order to study slow movements of soil and ground on turf-covered slopes (creep), the authors have resumed studies and also started to hold stationary observations in the Greater Volga-Kama Biosphere Reserve by UNESCO. The research in this area started in 2007, and the ideas of a widespread expansion of slow soil movements on turf-covered slopes were further developed.

\section{Methods}

To solve an important research question in the study of the relief formation dynamics is to study the processes of creep and defluxion (Kurbanova et al., 2014, Pope et al., 2014). In this case the soil movement on slopes and on upper stratum of floodplain alluvium was analyzed in the longitudinal and transverse directions (at the soil surface along the surface slope), according to the river flow rate and the slope of the river, and according to the change of this displacement in relation to depth (Wilkinson et al., 2007; Dedkov et al., 2005).

The study of displacement in the longitudinal direction was carried out by means of benchmarks, driven into the soil to ground level and originally located strictly on a straight line perpendicular to the valley. The benchmarks' displacement was assessed annually relatively to this line.

The change of displacement in relation to depth was studied on plates inserted along the plumb line in the two walls of the dig site both parallel and perpendicular to the river flow till the depth of $1.5-1.7 \mathrm{~m}$ after $5-10 \mathrm{~cm}$. 
When organizing pin-point stationary study areas for the creep study the authors used a very simple in a technical relation technique by A.P. Dedkov, V.A. Duglav and V.I. Mozzherin. A total of 10 test dig sites were dug with the depth range of $1.4-1.8 \mathrm{~m}$. As planned these dig sites were located on 3 lines. The first line lied on the left bank of the river Sumka, on the gentle forested slopes of the northwestern exposure; the second - on the right convex-concave slope of the south-eastern and eastern exposure and the third - on the gentle treeless (meadow) slopes of the right bank of the river Sumka. The distance between the dig sites on the lines was on average 250 - 320 m. (Kurbanova et al., 2014).

\section{Results}

Through years of research the floodplains of various levels were tested which were various relatively to the water edge and valley slopes, various in landscape confinement, exposure, geological structure and mechanical composition of soil. The catchment area of the studied rivers varied from 10 to $300 \mathrm{~km} 2$, the length - from 10 to $100 \mathrm{~km}$, the width consisted of the first few hundred meters. According to the results of the stationary study on defluxion a considerable amount of field data was collected, methods of study were developed, a mechanism and conditions for manifestation of the soil displacement processes on slopes and floodplains were determined.

Our stationary observations of small rivers' floodplains of the I and III order according to the Straler-Filosofov system (with the length range of $2-12 \mathrm{~km}$, with a catchment area of $5-73$ square kilometers and slopes of $0.02-0.001$ ) found that the floodplain alluvium is experiencing a very slow displacement down the valley. Observations were made in the valleys of the following rivers: Nurminka, Morkvashka, Ulema, Kolunets, Vala, and brooks: Nosov, Multasshe, Suladzhi, Temev (feeders of Mesha, Sviyaga, Vyatka, Kil'mez) in the Middle Volga.

The highest rate of displacement is observed in the dig site, laid at a river channel (dig site1). It exceeds the displacement of the soil in the dig site 4 (at rear seam of the floodplain) by 2 - 3 times. The displacement of plates along the slope to the river is $1.6-1.8 \mathrm{~mm} /$ year, what is more the displacement at the bed is also almost 1.5 - 2 times bigger than at the "rear part" of the floodplain. However, the analysis of the movement rate of the floodplain alluvium at river stations located both in the upper and in the lower reaches of the river, did not show any significant changes during the process of defluxion. On average, it was about $3 \mathrm{~mm} /$ year.

Observations of creep which took place on the slopes of the studied area were held in dig sites with the depth of $1.5 \mathrm{~m}$. At the base of the dig's side wall the metal rod with the length of $0.5-0.6 \mathrm{~m}$. was driven in horizontally. At the end of the rod with the use of a level a vertical guide line was put over which at the side wall of the dig site thin metal plates of 4 squire $\mathrm{cm}$ were placed strictly along the slope. Then the dig site was buried, the bulk soil was artificially compacted, and an accurate dig site fixation was done. After 3 - 4 years some dig sites were opened, and the measurements of the plates' deflection along the slope line were made.

The studied area (the gentle treeless slope of the right bank of the river Sumka) is located on the right bank of the Sumka river valley approximately $2.5 \mathrm{~km}$ to the northeast from the village Belobezvodnoe, azimuth $296^{\circ}$, in the middle of the hollow surface inclined to the river Sumka of the II floodplain terrace. The dig site was laid in July 2007 and opened in August 2013. The soil depth is $1.58 \mathrm{~m}$. 30 plates were driven into the side wall of the dig site. The data on the benchmark (plates) displacement are shown in Table 1. The steepness of the terrace surface does not exceed $4-5^{\circ}$. The general slope of the surface as a whole is oriented to the south-southeast. The mechanical composition of the soil of the terrace top part is dominated by clay-silt varieties (upper section) and strongly sanded and medium loamy measures (in the middle and lower parts of the section). On the terrace' surface there is an abandoned field with herbaceous vegetation.

Table 1. Quantitative characterization of soil displacement on the right bank of river Sumka

\begin{tabular}{|c|c|c|c|}
\hline $\begin{array}{c}\text { Number of } \\
\text { benchmarks }\end{array}$ & Depth, cm & $\begin{array}{c}\text { Horizontal displacement } \\
\text { component for 6 years, } \mathrm{mm}\end{array}$ & $\begin{array}{c}\text { Average displacement value } \\
\text { for 1 year, mm }\end{array}$ \\
\hline 2 & 11,7 & 12,5 & 2,08 \\
\hline 5 & 26,4 & 11,3 & 1,88 \\
\hline 7 & 36,5 & 10,5 & 1,75 \\
\hline 11 & 56,6 & 8,0 & 1,33 \\
\hline 20 & 100,6 & 2,5 & 0,42 \\
\hline 25 & 124,2 & 0,4 & 0,07 \\
\hline 30 & 150,3 & 0 & 0 \\
\hline
\end{tabular}

The change of displacement in relation to depth was studied by the plates inserted along the plumb line in the two dig site 
walls both parallel and perpendicular to the river flow to a depth of $1.5-1.7 \mathrm{~m}$ in $5-10 \mathrm{~cm}$. The position of the plumb line is tied to the rod driven into the dig's bottom. When laying the dig sites we considered their position on the floodplain or terrace.

Opening of dig sites happened after 3 - 4 years. After opening, the plates' deviation from the plumb line was recorded, i.e. the horizontal displacement component was measured. On the studied area the movement was not accompanied by any noticeable deformation of the soil surface, so we can assume that the movement of the particles was mainly parallel to the slope. The horizontal component and the slope angle $\left(5^{\circ}\right)$ can determine the amount of soil displacement downslope by the formula:

$$
a=\frac{b}{\cos 5^{\circ}},
$$

where $a$ - the amount of movement of the particles parallel to the slope, $b$ - horizontal component of this amount.

The results have showed (Fig. 1) that the displacement of soil in relation to depth occurs at different rates. The average displacement value is $0.5-1.3 \mathrm{~mm} /$ year. With depth the movement rate decelerates and at a depth of 100 $120 \mathrm{~cm}$ it is reduced to $0.1-0.5 \mathrm{~mm} /$ year, that is, almost dies out.

A comparison of the displacement value of soil and its content of fine particles shows that the decrease in the movement rate with the increase of the depth (Fig. 1) cannot be explained by changes in the mechanical composition of soil. Indeed, the smallest rates are observed in the lower layers of soil which have a higher content of fine particles.

For floodplains of small rivers of the Middle Volga, as for all of the channel facies of the normal alluvium the clear predominance of the coarse sand fraction is distinctive.

The marked decrease in displacement values in relation to depth is due to the mechanism of soil movement on slopes. These movements are of hydrothermal nature and are due to variations in moisture and temperature of soil, slope inclination of slopes and bottom channel, including freezing and thawing. Fluctuations in humidity and temperature lead to periodic changes in the volume of soil (Foulds, 2013; Panin, 1997). Thanks to them the soil develops tension which is directed in all directions. But the gravitational forces are added to the tension directed down the slope; therefore the displacement of particles down the slope exceeds the displacement in other directions. Since the fluctuations in temperature and humidity are greatest at the surface, it is quite natural that the surface soil is experiencing the largest displacement. Table 2 shows the morphometric data of some rivers of the Middle Volga and also the absolute values and movement rates of the alluvium displacement. The maximum rate of displacement was indicated by the benchmark which shifted to the largest value. Studies have shown that the maximum displacement occurred at the bed, the minimum - at the rear seam, with displacement which increased gradually.

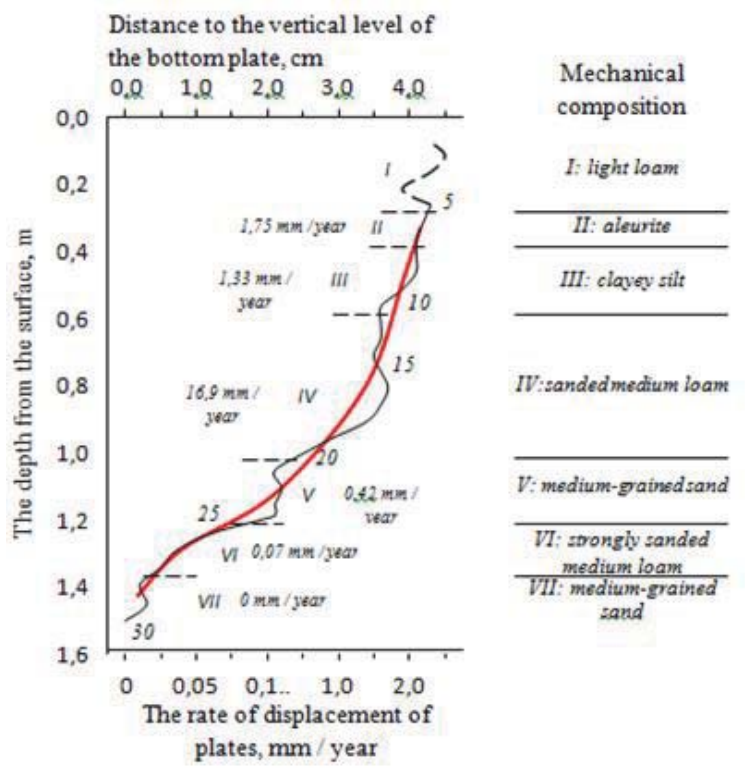

Fig.1. The curve of the average displacement rates of plates in the dig sites of the Sumka river valley. Symbols of the curve:

In cursive the numbers of plates are signed. In semi bold and in a thick red line the average displacement rates of plates at separate layers (mechanical composition) are indicated. For the top four plates the rate curve is shown approximately (with the broken line) because the plates 1-4 lost a strictly horizontal position and lean in the dig's wall in all directions(disoriented).

At floodplains where there is a forest or bush vegetation, the shift is very slow (Table. 2). 
Table 2. Benchmark displacement at floodplains of some small rivers of the Middle Volga from 1983 to 2003

\begin{tabular}{lccccccc}
\hline River and basin & $\begin{array}{c}\text { Basin } \\
\text { area, } \mathrm{km}^{2}\end{array}$ & $\begin{array}{c}\text { River } \\
\text { length, } \mathrm{km}\end{array}$ & $\begin{array}{c}\text { River } \\
\text { fall }\end{array}$ & $\begin{array}{c}\text { Observation } \\
\text { period, years }\end{array}$ & $\begin{array}{c}\text { Floodplain } \\
\text { condition }\end{array}$ & $\begin{array}{c}\text { Maximum } \\
\text { displacement, cm }\end{array}$ & $\begin{array}{c}\text { Displacement } \\
\text { rate, cm/year }\end{array}$ \\
\hline Kolunets (Ulema) & 21,0 & 4,0 & 0,010 & 15 & Meadow & 76 & 5,1 \\
Nosov (Ulema) & 36,8 & 9,3 & 0,002 & 15 & Meadow & 90 & 6,0 \\
Knya (Burets) & 73,4 & 12,0 & 0,005 & 18 & Meadow & 78 & 4,3 \\
Morkvashka (Volga) & 43,5 & 10,0 & 0,001 & 20 & Bushes & 22 & 1,1 \\
Malinisky & 3,7 & 2,0 & 0,020 & 15 & Forest & 5 & 0,3 \\
Nurminka (Vyatka) & 14,9 & 4,3 & 0,014 & 20 & Meadow & 98 & 4,9 \\
\hline
\end{tabular}

For example, during 15 - 20 years at the forested floodplains (brook Malininsky, river Morkvashka), the benchmarks shifted by maximally $5-22 \mathrm{~cm}$, i.e. the movement rate of the soil is $0.3-1.1 \mathrm{~cm}$ year, while at approximately the same conditions the movement rate of the alluvial in meadow floodplains of other rivers increases to $4-6 \mathrm{~cm}$.

The change of displacements in relation to depth was studied on the river Nurminka of the right feeder of Vyatka. The bottom of the river is occupied by the floodplain with the width of $20-30 \mathrm{~m}$, the slope of the river in the upper reaches is 0,014 , at the downstream -0.008 , the length of the river is $11 \mathrm{~km}$. Up to the depth of $1.5-2 \mathrm{~m}$ the floodplain of the river consists of loam soil, sandy loam with occasional streaks of sand and gravel.

The study of defluxion for a sufficiently long period of time has made it possible to trace its dynamics in its 30-year time interval. In recent decades, with the beginning of economic reforms in the agricultural sector the fundamental changes took place. From 1989 to 2002 the area of lands decreased by almost 5\%, with farm fields decreased by 5\%, and the area of hayfields, pastures, wastelands (which started to overgrow with secondary forest) increased to $4.5 \%$.

It was during this period that at such overgrown floodplains the average rate of displacement of the upper soil has decreased by more than 2 times - from $3.5 \mathrm{~mm} / \mathrm{yr}$ to $0.8 \mathrm{~mm} /$ year.

The mechanism of a floodplain alluvium movement is apparently due to the fact that during the flood the floodplain soil acquires not only viscoplastic, but perhaps a plastic consistency contributing to its displacement. Moreover, at this time they experience a large hydrostatic and hydrodynamic pressure of high waters. These reasons, obviously, cause an intense displacement of the upper horizons of alluvium even with a small slope of the floodplain. But the flow of soil, similar to solifluction, apparently, does not occur, because the shifted layer completely lacks any textural features characteristic in solifluction.

\section{Conclusions}

The conducted research work on studying the topography at the Raifa Reserve territory was carried out in accordance with the methodology, the most optimal in terms of quality, time spent and technical capabilities (Sycheva, 1999; Dedkov et al., 2005; Rosenbloom et al., 1998).

Similar results of stationary studies of the soil movement on turf-covered slopes were obtained in different parts of the Middle Volga (rivers Ulema, Knya, Nurminka, Vala, Sumka) both on slopes and at bottoms of river valleys. The soil displacement was recorded in all dig sites to a depth of $80-140 \mathrm{~cm}$ (the average thickness of a displaced layer is 110 $\mathrm{cm}$ ). Besides of the movement of the floodplain alluvium along the slope of the bottom of the valleys, within the study period it was observed that the alluvium moved along the slope to the river, i.e. during floods and high water, under gravity the hydromorphic soil experiences the shift to the mainstream. The horizontal component of the displacement amounts to $2-5 \mathrm{~mm} /$ year. Its maximum value measured by 2 plates in the digs number 7 and 9 , is $9 \mathrm{~mm} /$ year. The same values were obtained in the other areas of the temperate zones (Kurbanova et al., 2014; Richardson et al., 2014; Knox, 2001, 2006, etc.) and they can be considered as typical. In relation to depth the horizontal component decreases particularly fast up to the depth of $25-50 \mathrm{~cm}$.

The results showed that both creep processes on slopes and the displacement of alluvium in floodplains occur at different rates, but their distribution is indicative of a slow displacement of the slope and floodplain material. The rate curves are similar, although from the observations of the slope and floodplain processes, the rate in river valleys is higher by 0.5-1 times within $0.5 \mathrm{~m}$ than it is on slopes.

In general, the stationary observations of the accumulation intensity and the displacement of the floodplain clay sheet on small rivers of the Middle Volga showed that the bottoms of small rivers in addition to the accumulation developed a process similar to slope defluxion - viscoplastic soil shift that is due to the gravity. The average value of the soil displacement on slopes is $0.5-1.3 \mathrm{~mm} /$ year, of the floodplain alluvium - $1.5-5.2 \mathrm{~mm} /$ year. However, in all the dig 
sites at the surface layer the average rate of alluvium displacement is 2 - 6 times more. With depth the movement rate slows down and at the depth of $50-70 \mathrm{~cm}$ (in floodplains), $100-120 \mathrm{~cm}$ (on slopes), it is reduced to $0.1-1.0 \mathrm{~mm} /$ year, i.e., almost dies out. Our own stationary observations confirm the existence of slow soil movements on turf-covered slopes and floodplains of small rivers.

Further studies of exploring the mechanism of formation of relief-forming processes, predicting and identifying the dynamics of the modern exogenous processes such as creep and defluxion, present a great interest.

\section{References}

Dedkov A.P., V.I. Moszerin, A.N. Sharifullin and R.R. Denmukhametov. Recent denudation of the Earth's plains according to data on sediment and dissolved substance load. Isvestiya Akademii Nauk, Seriya Geograficheskaya, 2005, Issue 5: pp. 30-38.

Foulds S.A., M.G. Macklin and P.A. Brewer. Agro-industrial alluvium in the Swale catchment, northern England, as an event marker for the Anthropocene. Holocene, 2013, 23(4): pp. 587-602.

Knox J.C. Agricultural influence on landscape sensitivity in the Upper Mississippi River Valley, 2001, vol. 42, Issue 2-4: pp. 193-224.

Knox J.C. Floodplain sedimentation in the Upper Mississippi River Valley: Natural versus human accelerated. Geomorphology, 2006, vol. 3,4, Article number 79: pp. 286-310.

Kurbanova, S.G.,Denmukhametov, R.R.,Sharifullin, A.N. Assessment of speed of the recent floodplain alluvium accumulation in basins of minor rivers of the East of the Russian plain. Life Science Journal, 11 (11), 82, pp. 480-483.

Kinossian, N., Morgan, K. (2014). Development by Decree: The Limits of 'Authoritarian Modernization' in the Russian Federation. International Journal of Urban and Regional Research, 38 (5), pp. 1678-1696.

Panin A.V., N.N. Ivanova and V.N. Golosov. The river network and the processes of erosion and accumulation in the Upper Don basin. Water Resources, 1997, 24(6): pp. 609-617.

Pope I.C., Odhiambo B.K. Soil erosion and sediment fluxes analysis: a watershed study of the Ni Reservoir, Spotsylvania County, VA, USA // Environmental monitoring and assessment, 2014, vol. 186, Issue 3: pp. 1719-1733.

Richardson J.M., I.C. Fuller and K.A. Holt. Rapid post-settlement floodplain fccumulation in Northland, New Zealand. Catena, 2014, 113: pp. 292-305.

Rosenbloom, N.A., S. C. Doney and D. S. Schimel (1998) Hillslope mass transport, catenary sequences, and soil organic matter: Numerical simulations and model-data comparisons of the CREEP model for Great Plains grassland environments. Presented at the 1998 Fall Meeting of the American Geophysical Union. San Francisco, CA. December 1998. EOS Abstract. 79(45): pp.264.

Gaisin, I.T., Beketova, S.I., Gaisin, R.I. Competence-based approach as an effective way to increase the level of training of geographers in universities // Life Science Journal 2014;11(11 s)C.166-170.http//www.lifesciencesite.com

Smirnova, E.V., Urazmetov, I.A. (2014). Specifics of land cover of natural anthropogenic landscapes in oil production regions. International Multidisciplinary Scientific GeoConference Surveying Geology and Mining Ecology Management, SGEM, 1, pp. 765770.

Sycheva S.A. Cycles of soil formation and accumulation in the Holocene (according to C-14 data) // Eurasian soil science, 1999, vol. 32, Issue 6: pp. 613-623.

Wilkinson B.H., McElroy B.J. The impact of humans on continental erosion and sedimentation // Geological society of America bulletin, 2007, vol. 119, Issue 1-2: pp. 140-156.

Denmukhametov, R.R., Zjablova, O.V., Shtanchaeva, M.R. Development factors of Kazan region recreation area. Life Science Journal, 11 (11), pp. 317-320 